\title{
Tissue Distribution and Regulation of Plasminogen Activator Inhibitor-1 in Obese Mice ${ }^{1}$
}

\author{
F. Samad and D. J. Loskutoff \\ The Scripps Research Institute, Department of Vascular Biology, \\ La Jolla, California, U.S.A.
}

\begin{abstract}
Background: Although elevated plasminogen activator inhibitor-1 (PAI-1) is associated with obesity and may be a risk factor for cardiovascular disease, the mechanism(s) that lead to this elevation, and the tissue/cellular origins of this increase, remain to be defined. In this report, we have addressed these questions using genetically obese mice (ob/ob) and their lean counterparts $(+/$ ?).

Materials and Methods: PAI- 1 activity and antigen levels were determined using a tissue-type plasminogen activator (t-PA) binding assay and Western blotting. The concentration of PAI-1 mRNA in tissues was determined by quantitative reverse transcriptase-polymerase chain reaction (RT-PCR), and the cellular localization of PAI-1 was evaluated using in situ hybridization, immunohistochemistry, and cell fractionation.

Results: PAI-1 activity was approximately 4-fold higher in plasma from ob/ob mice than in that obtained from their lean counterparts, and this difference increased

further with age (i.e., 6-fold at 3 months). PAI- 1 mRNA levels were elevated 4- to 5-fold in the adipose tissues of obese mice, and these differences in mRNA also increased with age. The elevated PAI- 1 mRNA in the adipose tissues of obese mice was localized to mature adipocytes as well as to vascular smooth muscle cells and occasional endothelial cells. Obesity is often associated with hyperinsulinemia, and acute injection of insulin into lean mice increased PAI-1 mRNA 6-to 8-fold in the epididymal fat in cells that morphologically resembled adipocytes. Insulin did not increase PAI-1 in large vessel endothelial or smooth muscle cells. The adipocyte response to insulin was confirmed in cell culture studies where PAI- 1 synthesis by mature 3T3-Ll adipocytes was increased 5- to 6-fold by insulin.

Conclusions: Our results suggest that elevated PAI-1 associated with obesity may result in part from insulininduced induction of PAI-1 specifically by adipocytes within the fat itself.
\end{abstract}

\section{INTRODUCTION}

Obesity is an independent risk factor for the development of atherosclerosis and cardiovascular disease $(1,2)$ and is associated with related metabolic disorders such as hypertriglyceridemia, hyperinsulinemia, and non-insulin-dependent diabetes $(2,3)$. Interestingly, in a limited number of clinical studies, significant correlations have been established between elevated plasminogen activator inhibitor-1 (PAI-1) levels and obesity (4-7), and this abnormal expression of PAI- 1 has

Address correspondence and reprint requests to: David J. Loskutoff, The Scripps Research Institute, $10666 \mathrm{~N}$. Torrey Pines Road, VB-3, La Jolla, CA 92037, U.S.A.

${ }^{1}$ This work was presented in part at the XIIth International Congress on Fibrinolysis, September 1994, in Leuven, Belgium. been associated with increased risk for cardiovascular disease $(8-11)$. In spite of these results, very little is known about the tissue or cellular origin of this elevated PAI-1, or about the mechanism(s) that leads to increased PAI-1 under obese and diabetic conditions. Limited clinical studies demonstrate that surgical treatment of morbid obesity by either gastric stapling or jejuno-ileal bypass, two treatments that lead to dramatic weight loss, also reduce PAI-1 activity and clot lysis time significantly (12). These observations suggest that elevations in plasma PAI-1 levels associated with obesity may result from the constitutive synthesis of PAI-1 by the adipose tissue itself. In this regard, previous studies on the normal tissue distribution of PAI-1 in mice demonstrated high concentrations of PAI-1 
mRNA in the epididymal fat pad (13). In obese animals, the mass of the epididymal fat pad typically increases several-fold, primarily because of an increase in the size and number of adipocytes. Thus, in obesity, the PAI-1 biosynthetic capacity of the adipose tissue would be expected to exceed that of all other tissues.

Increased levels of PAI- 1 also are associated with the insulin-resistant syndrome (14), and a significant correlation was demonstrated between plasma PAI-1 levels and body mass index, serum triglyceride levels, fasting and 2-hr plasma insulin levels, and hypertension $(7,15,16)$. In obese humans, elevations in plasma PAI-1 appear to correlate with plasma insulin levels (17), and PAI-l levels have been shown to be inversely correlated with insulin sensitivity $(5,15,18)$. Thus, increased PAI- I may be a positive link between insulin resistance and coronary heart disease. The finding that insulin-resistant individuals have high plasma PAI-l levels (18) further suggests that the elevated PAI-1 detected in obesity may be induced, in part, by plasma insulin. In this respect, modulation of insulin resistance with diet, exercise, or oral antidiabetic drugs such as metformin simultaneously decreased both plasma insulin and plasma PAI- 1 in obese subjects (19). Insulin has also been reported to increase PAI-1 production in cultured hepatocytes (20-22), suggesting that increased hepatic synthesis of PAI-1 may account for its elevation in obese subjects.

Studies of obese rodents and humans demonstrate that the adipose tissue is a major site of synthesis of tumor necrosis factor $\alpha$ (TNF $\alpha)$, and that its expression is elevated in obesity $(23,24)$. Interestingly, TNF $\alpha$ also stimulates PAI- 1 expression in a variety of cultured cells and in most murine tissues, including the epididymal fat pad $(25,26)$. Taken together, these results suggest that both insulin and TNF $\alpha$, two agents that are elevated in obesity and related NIDDM, are also capable of inducing PAI-1 in many systems.

In a previous study, we showed that PAI- 1 is synthesized by adipocytes from normal CB6 mice and by cultured 3T3-L1 adipocytes (27), and that its expression by these cells was induced by TNF $\alpha$ treatment. Based on these studies, we hypothesized that the basal and/or TNF $\alpha$-induced level of PAI-1 expression by cells of the adipose tissue itself may contribute to the elevated PAI- 1 level observed under obese conditions. In the present study, we have employed genetically obese mice $(\mathrm{ob} / \mathrm{ob})$ and their lean counterparts $(+/$ ?) to determine the tissue and cellular distribution of
PAI-1 under obese conditions and to study the sensitivity of murine tissues to insulin. Our results suggest that increases in insulin in obesity may induce PAI-l synthesis specifically in the adipose tissue. These increases, together with increases induced by TNF $\alpha$ (27), may account for the elevated PAI-1 associated with obese conditions.

\section{MATERIALS AND METHODS}

\section{Tissue Preparation}

Adult male obese mice (C57BL/6J ob/ob; Jackson Labs, Bar Harbor, ME, U.S.A.) and their lean counterparts (C57BL/6J +/?) aged 4-12 weeks were anesthetized and blood collected into 20 mM EDTA (final concentration) to prevent clotting. For in vivo insulin experiments, lean mice were injected intraperitoneally with 10 units of regular human insulin (Humulin R; Eli Lilly, Indianapolis, IN, U.S.A.), while the controls were injected with an equivalent volume of saline alone. At the conclusion of experiments, mice were sacrificed by overdose inhalation of metofane and cervical dislocation. Tissues were rapidly removed and immersed in chilled $4 \%$ paraformaldehyde (for in situ hybridization and immunohistochemistry) or minced and frozen in liquid nitrogen for preparation of total RNA. The paraformaldehyde fixed (overnight) tissues were embedded in paraffin blocks, and sectioned at 2to $5-\mu$ thickness using a microtome. The sections were then mounted onto Superfrost/plus microscope slides (Fisher Scientific, Pittsburgh, PA, U.S.A.) and stored at room temperature pending analysis.

\section{Determination of PAI-1 Activity and Glucose and Insulin Levels in Plasma}

PAI- 1 activity in plasma was determined using the tissue-type plasminogen activator (t-PA) binding assay as previously described (28). The polyclonal rabbit anti-mouse PAI-1 antibody used in this assay was prepared against purified, recombinant mouse PAI-1, (a kind gift from Drs. D. Lawrence and D. Ginsburg, Howard Hughes Medical Institute, University of Michigan Medical Center, Ann Arbor, MI, U.S.A.). Active PAI-1 levels $(\mathrm{ng} / \mathrm{ml})$ were calculated from a standard curve constructed using recombinant mouse PAI-1. Plasma glucose levels were determined using the hexokinase assay according to manu- 
facturers directions (Sigma Chemical Co., St. Louis, MO, U.S.A.). Plasma insulin levels were determined using a rat insulin RIA kit (Linco Research Inc., St. Charles, MO, U.S.A.). This assay, which shows $100 \%$ cross-reactivity with both mouse and human insulin, enabled us to estimate the total concentration of insulin in the blood of lean mice after intraperitoneal injection of human insulin.

\section{Northern Blot Analysis}

Total RNA was extracted from various tissues of obese and lean mice by the acid guanidinium thiocyanate-phenol-chloroform method (29), and its concentration was determined by sample absorbance at $260 \mathrm{~nm}$. Total RNA (15 $\mu \mathrm{g}$ ) was analyzed by Northern blotting as described previously (30) employing a l-kb murine PAI- 1 cDNA probe. The probe was labeled by the random primer technique (31) using $\alpha-\left[{ }^{32}\right.$ P]dGTP (>3000 Ci/mmol; Amersham Corp., Arlington Heights, IL, U.S.A.). Autoradiography was performed at $-70^{\circ} \mathrm{C}$ using Kodak XAR-5 film with intensifying screens. To assess variability in sample loading, Northern blots were stripped and rehybridized with a radiolabeled CDNA encoding rat 18S RNA.

\section{Quantitative Polymerase Chain Reaction}

The concentration of PAI-1 mRNA was also determined using a quantitative polymerase chain reaction (PCR) procedure as described previously (32). A synthetic plasmid was first constructed and used as an internal standard (33). This plasmid was constructed by cloning the following sequences into the multiple cloning site of the vector pBluescript $11 \mathrm{KS}+$ (Stratagene, La Jolla, CA, U.S.A.): the sequences of upstream primers for PAI- 1 (5'-TCAGAGCAACAAGTTCAACTA CACTGAG- $\left.3^{\prime}\right)$ and $\beta$-actin genes ( $5^{\prime}$-TGGAA TCCTGTGGCATCCATGAAAC-3') followed by their corresponding downstream primers (PAI1:5'-CCCACTGTCAAGGCTCCATCACTTGCCC CA-3'; $\beta$-actin: 5'-TAAAACGCAGCTCAGTAAC AGTCCG-3').

An internal RNA standard (cRNA) was transcribed off the linearized (Kpnl) synthetic plasmid from the T7 promoter, using the Riboprobe Gemini 11 in vitro transcription system, according to the manufacturers instructions (Promega, Madison, WI, U.S.A.). Reverse transcription (RT) and PCR (using either $10^{6}$ or $10^{7}$ molecules of cRNA for PAI- 1 and $10^{7}$ for $\beta$-actin, optimized in previous preliminary experiments) were performed essentially as described (34). Aliquots (20 $\mu \mathrm{l})$ of the PCR products were electrophoresed on $1.8 \%$ agarose gels containing ethidium bromide. The appropriate bands corresponding to the internal standard cRNA product and the target mRNA product were excised from the gel and the incorporated radioactivity quantified using a scintillation counter. A standard curve for the internal control cRNA was constructed and employed to extrapolate the number of molecules of PAI- 1 mRNA/ $\mu$ g total RNA and the specific activity of PAI-1 mRNA as previously described $(27,32)$. Variations in sample loading were assessed by measuring $\beta$-actin mRNA.

\section{Riboprobe Preparation}

A subclone of mouse PAI-1 cDNA containing nucleotides $1-1085$ in the vector pGEM-3Z was used to prepare a riboprobe for in situ hybridization (35). This vector was linearized with EcoR 1 (antisense) or Hindlll (sense) and used as a template for in vitro transcription of radiolabeled antisense or sense riboprobes employing SP6 or T7 RNA polymerase respectively, in the presence of $\left[{ }^{35}\right.$ S ]UTP (>1200 Ci/mmol; Amersham). Templates were removed by digestion with $R Q 1$ DNAse (Promega) for $15 \mathrm{~min}$ at $37^{\circ} \mathrm{C}$, and the riboprobes were purified by phenol extraction and ethanol precipitation.

\section{In Situ Hybridization}

In situ hybridization was performed as described previously (35). Briefly, paraffin-embedded tissue sections $(3-5 \mu)$ were pretreated sequentially with xylene $(3 \times 5 \mathrm{~min}), 2 \times \mathrm{SSC}(300 \mathrm{mM}$ $\mathrm{NaCl}, 30 \mathrm{mM}$ sodium citrate, $\mathrm{pH} 7.0$, containing $10 \mathrm{mM}$ 2-mercaptoethanol, $1 \mathrm{mM}$ EDTA) $(1 \times$ $10 \mathrm{~min})$, paraformaldehyde $\left(1 \times 10 \mathrm{~min}, 4^{\circ} \mathrm{C}\right)$ and proteinase $\mathrm{K}(1 \mu \mathrm{g} / \mathrm{ml}$ in $500 \mathrm{mM} \mathrm{NaCl}, 10$ $\mathrm{mM}$ Tris- $\mathrm{HCl}, \mathrm{pH} \mathrm{8.0})(1 \times 10 \mathrm{~min})$. Slides were then prehybridized for $2 \mathrm{hr}$ at $42^{\circ} \mathrm{C}$ in $100 \mu \mathrm{l}$ of prehybridization buffer $[50 \% \mathrm{w} / \mathrm{v}$ formamide, $0.3 \mathrm{M} \mathrm{NaCl}, 20 \mathrm{mM}$ Tris-Hcl, $\mathrm{pH} 8.0,5 \mathrm{mM}$ EDTA, $0.02 \%$ polyvinylpyrrolidone, $0.02 \% \mathrm{Fi}$ coll, $0.02 \%$ bovine serum albumin, $10 \%(\mathrm{w} / \mathrm{v})$ dextran sulfate, $10 \mathrm{mM}$ dithiothreitol]. An additional $20 \mu \mathrm{l}$ of prehybridization buffer containing $2.5 \mathrm{mg} / \mathrm{ml}$ of tRNA and $600,000 \mathrm{cpm}$ of the ${ }^{35} \mathrm{~S}$-labeled riboprobe was added and the slides were hybridized for $18 \mathrm{hr}$ at $55^{\circ} \mathrm{C}$. The slides were then treated sequentially with $2 \times$ SSC containing $10 \mathrm{mM}$ 2-mercaptoethanol, $1 \mathrm{mM}$ 
EDTA $(2 \times 10 \mathrm{~min})$, with RNAse A $(20 \mu \mathrm{g} / \mathrm{ml}$ in $500 \mathrm{mM} \mathrm{NaCl}, 10 \mathrm{mM}$ Tris- $\mathrm{HCl}(1 \times 30 \mathrm{~min})$, with $2 \times$ SSC ( $10 \mathrm{mM} 2$-mercaptoethanol, $1 \mathrm{mM}$ EDTA) $\left(1 \times 2 \mathrm{hr}, 60^{\circ} \mathrm{C}\right)$ and with $0.5 \times \mathrm{SSC}(2 \times$ $10 \mathrm{~min})$. The slides were dehydrated in a graded alcohol series containing $0.3 \mathrm{M} \mathrm{NH} 44 \mathrm{Ac}$, dried, coated with NTB2 emulsion (Kodak; 1:2 in water), and exposed in the dark at $4^{\circ} \mathrm{C}$ for 4 to 12 weeks. Slides were then developed for $2 \mathrm{~min}$ in D19 developer (Kodak), fixed, washed in water, and counterstained with hematoxylin and eosin. Parallel sections were hybridized using a sense probe as a control for nonspecific hybridization.

\section{Immunohistochemistry}

Immunohistochemical staining was performed using the HISTOSTAIN-SP kit (Zymed, South San Francisco, CA, U.S.A.) as described previously (35). Briefly, paraffin-embedded, paraformaldehyde-fixed sections were deparaffinized with xylene $(3 \times 5 \mathrm{~min})$, treated with $3 \%$ hydrogen peroxide to quench endogenous peroxidase activity, and rehydrated by immersion in a graded series of ethanol washes. All incubations and washes were performed at $25^{\circ} \mathrm{C}$ except where noted. Slides were washed for $10 \mathrm{~min}$ with Tris-buffered saline (TBS; $0.05 \mathrm{M}$ Tris- $\mathrm{HCl} /$ $0.15 \mathrm{M} \mathrm{NaCl}, \mathrm{pH} 7.4$ ) and then permeabilized by sequential treatment with $0.2 \%$ and $1 \%(\mathrm{v} / \mathrm{v})$ Triton $\mathrm{X}-100$ in TBS $(1 \times 10 \mathrm{~min}$ each $)$. To unmask tissue antigens, sections were incubated at $37^{\circ} \mathrm{C}$ with prewarmed $0.23 \%$ (w/v) pepsin $(3830 \mathrm{U} / \mathrm{mg}$, Worthington Biochemical Corp., Freehold, NJ, U.S.A.) in $0.01 \mathrm{~N} \mathrm{HCl}$ for $3 \mathrm{~min}$. Slides were rinsed with distilled water and with $0.2 \%$ Triton-TBS $(2 \times 3 \mathrm{~min})$, and then were incubated with $10 \%(\mathrm{w} / \mathrm{v})$ normal goat serum in TBS for $30 \mathrm{~min}$. Incubations with primary antibody (caprylic acid purified (36) rabbit antimouse PAI- $1 ; 10 \mu \mathrm{g} / \mathrm{ml}$ in $0.1 \%$ normal goat serum) or with normal rabbit IgG, were carried out in a humid chamber at $4^{\circ} \mathrm{C}$ for $16-18 \mathrm{hr}$, followed by incubation for $1 \mathrm{hr}$ at $25^{\circ} \mathrm{C}$. After washing with $1 \%$ Triton-TBS $(3 \times 3 \mathrm{~min})$, biotinylated goat anti-rabbit IgG (Zymed) diluted 1:100 in TBS containing $0.05 \%$ Tween 20 was added and the incubation was continued for 15 min. Sections were washed again with $1 \%$ Triton-TBS $(3 \times 3 \mathrm{~min})$, incubated for $10 \mathrm{~min}$ with streptavidin-peroxidase conjugate (Zymed), washed with $1 \%$ Triton-TBS $(3 \times 3 \mathrm{~min})$ and treated with freshly prepared aminoethylcarbazole chromogen containing $0.03 \%$ hydrogen peroxide for 5-15 min. The slides were washed in distilled water and counterstained with hematoxylin, rinsed well with tap water, and mounted in GVA-mount (Zymed).

\section{Cell Fractionation}

To verify elevated PAI-1 gene expression in adipocytes from the obese mice, we separated mature adipocytes from the stromal-vascular cells present in either the obese or lean mice as described (37). Briefly, epididymal fat pads were isolated from mice, washed in sterile PBS, minced, and washed in Krebs-Ringer bicarbonate (KRB) buffer ( $\mathrm{pH} 7.4$ ) containing $4 \%$ albu$\mathrm{min}$ and $5 \mathrm{mM}$ glucose. The tissues were then treated with collagenase $(2 \mathrm{mg} / \mathrm{ml}$; Sigma $)$ on a shaking platform at $37^{\circ} \mathrm{C}$ for $1 \mathrm{hr}$. Undigested tissue was removed with forceps, and the adipocytes were then separated from other cells by their ability to float upon low speed $(200 \times g)$ centrifugation. To obtain total stromal-vascular fractions, the medium below the adipocyte layer was centrifuged at $500 \times g$ for $10 \mathrm{~min}$, and the pellets were washed three times with warm KRB buffer. Total RNA was extracted from the two fractions and the amount of PAI-1 mRNA associated with each compartment was determined by quantitative PCR as described above.

\section{Cell Culture}

3T3-Ll mouse embryo fibroblasts were obtained from the American Type Culture Collection (Rockville, MD, U.S.A.). The culturing of these cells and their differentiation from preadipocytes to mature adipocytes was carried out as described previously (38). For treatment with insulin (bovine insulin, Sigma Chemical), the preadipocytes were differentiated into mature adipocytes in $100-\mathrm{mm}$ tissue culture plates. Total RNA was then isolated from the untreated but mature adipocytes, and from mature adipocytes treated with $100 \mathrm{nM}$ insulin for 3, 6, and $24 \mathrm{hr}$. Conditioned medium was also collected from untreated adipocytes and adipocytes treated with $100 \mathrm{nM}$ insulin for determination of PAI- 1 antigen levels.

\section{Western Blot Analysis}

PAI- 1 antigen in the conditioned medium from untreated and insulin-treated adipocytes was determined by Western blot analysis using the enhanced chemiluminescent (ECL) detection system (Amersham International plc., Bucking- 
hamshire, England). Briefly, conditioned medium $(20 \mu \mathrm{l})$ was electrophoresed under nonreducing conditions on a $9 \%$ SDS-PAGE gel and transferred to PROTRAN nitrocellulose membranes (Schleicher \& Schuell, Keene, NH, U.S.A.). The membranes were soaked in phosphate-buffered saline (PBS) containing 5\% casein and $0.1 \%$ Tween-20 for $1 \mathrm{hr}$ at room temperature to block additional protein-binding sites, and washed three times (15 min/wash) in PBS containing $0.1 \%$ Tween-20. The membranes were then incubated with a polyclonal rabbit antiserum specific for murine PAI-1 (1: 1000 dilution in PBS/0.1\% Tween-20), washed as before, and incubated for $30 \mathrm{~min}$ with a biotinylated goat anti-rabbit IgG (Zymed). After washing, the membranes were transferred to the VECTASTAIN ABC reagent made up according to manufacturers directions (Vector Laboratories, Burlington, CA, U.S.A.), incubated for $30 \mathrm{~min}$, and then washed several times over a period of 1 $\mathrm{hr}$ in PBS containing $0.1 \%$ Tween-20. The protein bands were visualized using the ECL Western blot detection system according to manufacturers instructions.

\section{RESULTS}

\section{Comparison of PAI-1 Levels in Plasma from Obese and Lean Mice}

A number of clinical studies have suggested that PAI- 1 is elevated in plasma from obese and diabetic individuals (4-7). To determine whether PAI- 1 activity was also elevated in plasma from obese mice, we collected plasma from 4-, 8-, and 12-week-old obese and lean mice and determined PAI-l activity using the t-PA binding assay (28). Figure 1 shows that PAI- 1 activity was approximately 3- to 4-fold higher in the plasma of 4-week-old obese mice when compared with that from their lean counterparts. Additionally, the PAI- 1 activity in the plasma of obese mice increased as a function of age, while that of lean mice remained remarkably constant over the period tested. Thus, the difference in the PAI-1 activity between obese and lean mice increased as the animals aged.

\section{Tissue Distribution of PAI-1 mRNA in Obese/Lean Mice}

Experiments were performed to determine the tissue origin of the elevated PAI- 1 detected in the

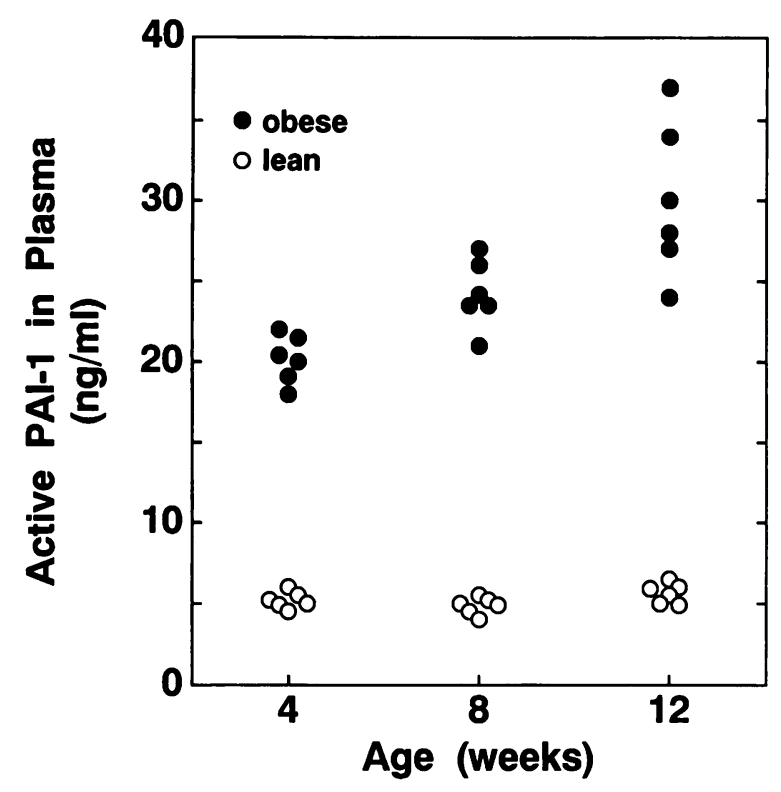

FIG. 1. PAI-1 activity in the plasma from obese $(o b / o b)$ and lean $(+/$ ?) mice

Plasma was collected from 4-, 8-, and 12-week-old lean $(\bigcirc)$ and obese (O) mice (six animals for each age), and the concentration of active PAI- 1 (ng/ml) was determined using the t-PA binding assay as described in Materials and Methods. Four weeks, mean $=20.3 \pm 1.4 ; 8$ weeks, mean $=24.2 \pm 2.1$; 12 weeks, mean $=30.0 \pm 4(n=6 \pm$ SD). Between 4 and 8 weeks, $p<0.001 ; 8$ and 12 weeks, $p<$ $0.01 ; 4$ and 12 weeks, $p<0.0003$ (unpaired $t$ test).

plasma of obese mice. Various tissues were removed from lean and obese mice, and total RNA was prepared and analyzed for PAI-1 mRNA by quantitative RT PCR (Fig. 2). In general, PAI-1 mRNA levels were approximately 4- to 5-fold higher in the epididymal, subcutaneous, and brown adipose tissues of obese mice compared with lean mice. A generalized induction (1.5- to 2 -fold) of PAI-1 mRNA was also observed in other major organs such as the heart, lung, muscle, liver, and kidney, suggesting the involvement of a systemic inducer. The increases in PAI-1 mRNA in the various adipose tissues of the obese mice was also detectable by Northern blot analysis, as shown in the inset. Thus, while most tissues from the obese mice contained higher levels of PAI-1 mRNA than those from their lean counterparts, the most dramatic increases were observed in the various adipose tissue depots. This pattern of PAI-1 gene expression suggests that the adipose tissue may be responsible in large part for the elevations of PAI- 1 observed in the plasma of obese mice. This hypothesis is sup- 


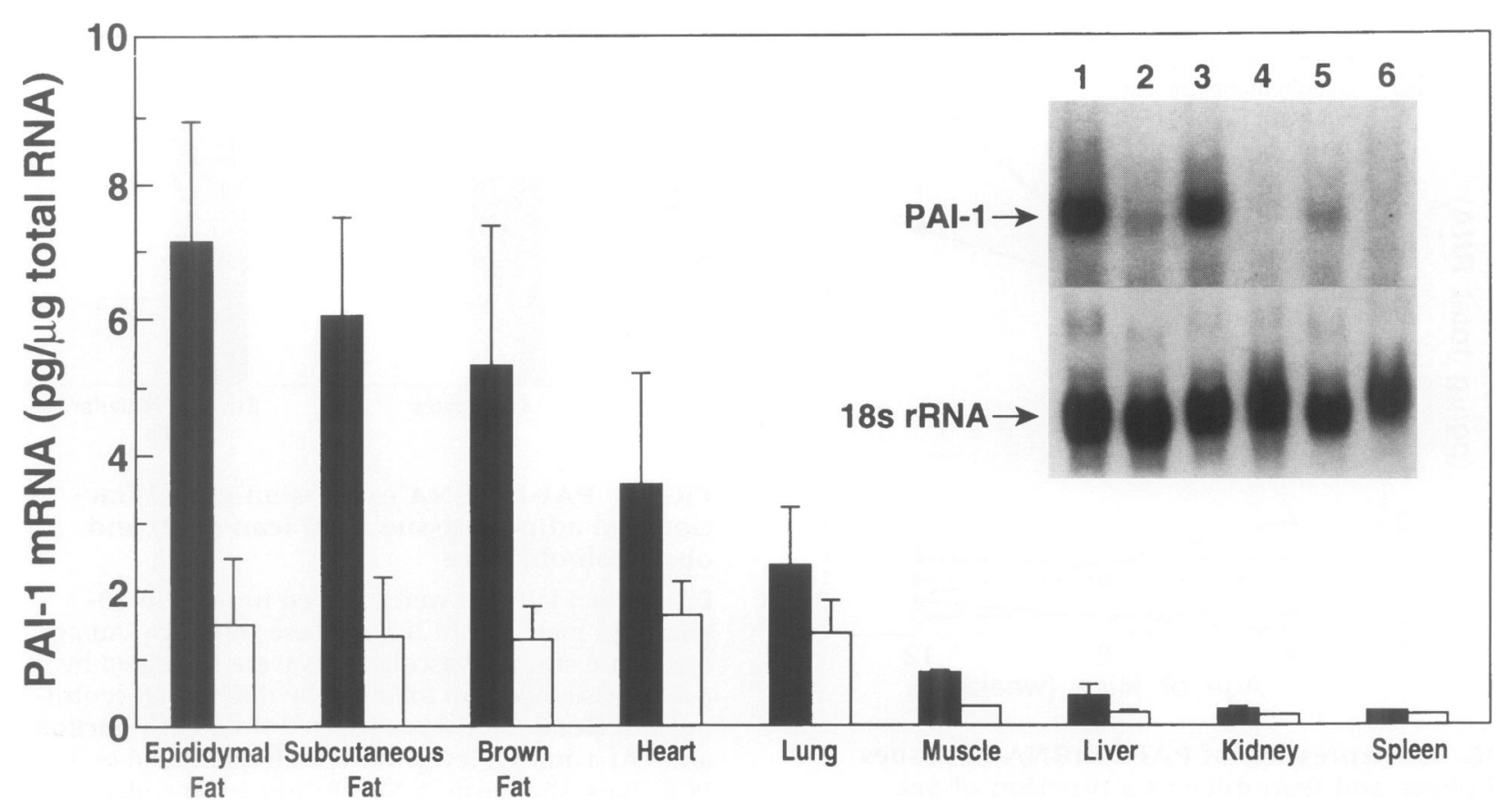

FIG. 2. Expression of PAI-1 mRNA in the tissues of lean and obese mice

Total RNA was extracted from 7- to 8-week-old male lean ( $\square$ ) and obese ( $\square$ ) animals and PAI-1 mRNA was determined using quantitative PCR analysis. $n=6 \pm$ SD. Inset: representative Northern blot showing PAI-1 mRNA expression in adipose tissues from obese (odd-numbered lanes) and lean (even-numbered lanes) mice. Lanes 1 and 2, epididymal fat; Lanes 3 and 4, subcutaneous fat; Lanes 5 and 6, brown fat. 18S rRNA is shown as a control for loading and for the integrity of the RNA.

ported by the observation that PAI-1 mRNA expression in the epididymal and subcutaneous adipose tissues of obese mice increased as a function of age (Fig. 3), whereas that of the lean mice remained unchanged over the age range tested. The concentration of PAI-1 mRNA in most other tissues of the obese mouse also was relatively constant over this period.

\section{Cellular Localization of PAI-1 in Adipose Tissue from Obese and Lean Mice}

Besides adipocytes, adipose tissue contains vascular endothelial cells, smooth muscle cells, fibroblasts, local mast cells, and macrophages (39). Experiments were performed to identify the cell type(s) expressing elevated PAI-1 mRNA in obesity. Adipose tissue was dissociated by collagenase treatment and subjected to differential centrifugation to separate mature adipocytes from the stromal/vascular cells as described (37). Cross-contamination of the mature floating adipocyte fraction with microvascular endothelial cells was evaluated by PCR analysis using von Willebrand factor (an endothelial cell marker [40])-specific primers as previously described (27). The amount of PAI-1 mRNA associated with the two cell fractions was then determined by RT-PCR (Fig. 4). Figure 4 shows that the mature adipocytes and stromal/vascular cell fractions from lean mice (open bars) contained 1.9 and $2.0 \mathrm{pg}$ PAI- $1 \mathrm{mRNA} / \mu \mathrm{g}$ total RNA, respectively, while these fractions from obese adipose tissue (closed bars) contained 5-6 pg/ $\mu$ g total RNA. Thus, PAI-1 mRNA levels were considerably higher in both the mature adipocyte fraction and the stromal/vascular cell fraction from obese mice.

Although the cell fractionation experiments shown in Fig. 4 implicate adipocytes in the elevated expression of PAI-1 mRNA, the identity of cells expressing elevated levels of PAI- 1 in the stromal/vascular fraction cannot be determined from this experiment. Thus, in situ hybridization experiments and immunohistochemistry were performed to identify further the cells within the adipose tissue contributing to elevated PAI-1 expression (Fig. 5). A very weak but consistent signal for PAI-1 mRNA was observed in the smooth muscle cell layer within the arteries of 


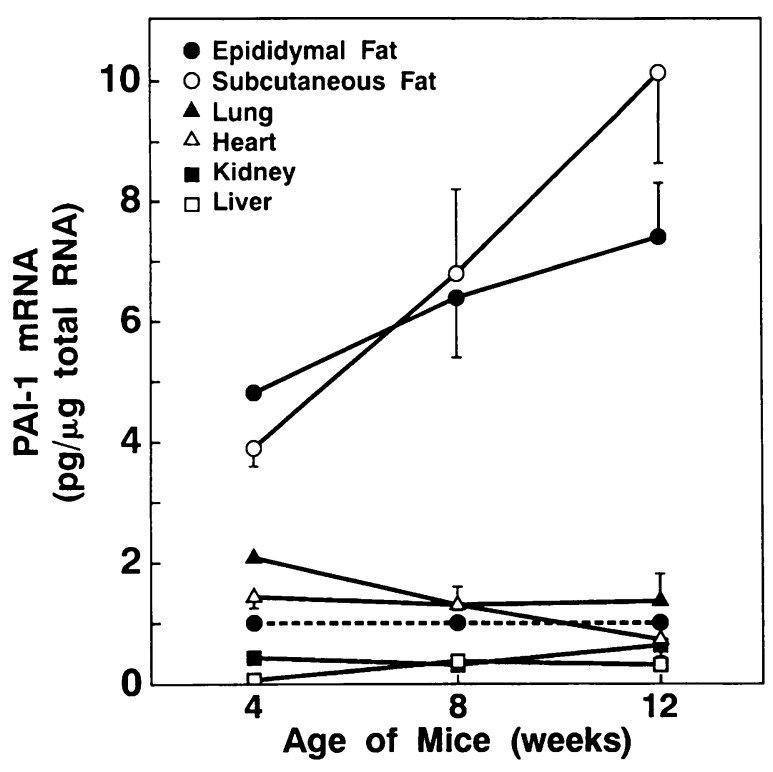

FIG. 3. Expression of PAI-1 mRNA in tissues of obese and lean mice as a function of age

Total RNA was extracted from the indicated tissues of 4-, 8-, and 12-week-old male obese (ob/ob) mice and the concentration of PAI-1 mRNA was determined using quantitative RT-PCR. Solid lines, tissues of obese mice; --- Epididymal fat pad of lean mice. $n=3 \pm$ SD. Epididymal fat: 4 and 8 weeks, $p<0.05 ; 8$ and 12 weeks, $p<0.1 ; 4$ and 12 weeks, $p<0.0004$. Subcutaneous fat: 4 and 8 weeks, $p<$ $0.01 ; 8$ and 12 weeks, $p<0.02 ; 4$ and 12 weeks, $p<0.0009$ (unpaired $t$ test).

the adipose tissue from lean mice (Fig. 5A). In contrast, the arteries within the adipose tissues from obese mice demonstrated a relatively strong signal for PAI-1 mRNA, and this was also localized to the smooth muscle cells of the tunica media (Fig. 5B). Interestingly, although large vessel of endothelial cells from lean mice were negative for PAI-1 mRNA (Fig. 5A), there were some positive endothelial cells in the arteries from obese animals (Fig. 5B, arrow). This general pattern of PAI-1 gene expression was relatively uniform throughout the vasculature of the adipose tissue (not shown). No PAI-1 mRNA was detected by in situ hybridization in the fat from lean mice (Fig. 5E). However, a positive signal was observed in more than $50 \%$ of the cells that morphologically resembled adipocytes in the fat from obese mice (Fig. 5F). Note that the obese adipocytes are also considerably larger than adipocytes from the lean mice (Fig. 5, compare E and F). Immunohistochemical analysis of the above tissue for PAI-1 revealed a similar pattern in that PAI-1 antigen was strongly expressed in

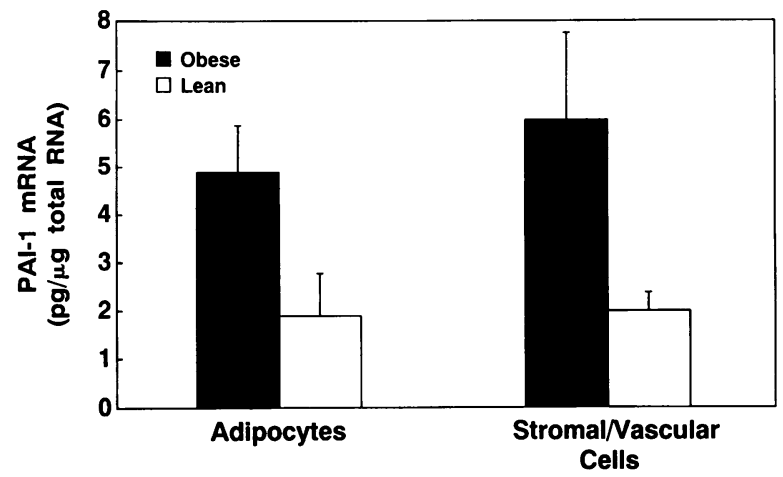

FIG. 4. PAI-1 mRNA expression in cell fractionated adipose tissue from lean $(+/$ ?) and obese (ob/ob) mice

Epididymal fat pads were isolated from 8- to 10week old male lean $(\square)$ and obese ( $\square$ ) mice. Adipocytes, and stromal vascular cells were separated by collagenase digestion followed by differential centrifugation. Total RNA was extracted from each fraction and PAI-1 mRNA levels were then quantified by RTPCR. Bars, the mean \pm SD of three independent experiments.

the arteries and fat of adipose tissue from obese mice (Fig. $5 \mathrm{D}$ and $\mathrm{H}$ ) but undetectable in adipose tissue from lean mice (Fig. $5 \mathrm{C}$ and G). In control experiments, no immunohistochemical staining was apparent in any tissues using normal rabbit serum, and no specific hybridization signal was detected using a sense PAI-1 riboprobe (data not shown).

\section{Effect of Insulin on Plasma PAI-1 Activity in Lean Mice}

Since circulating levels of insulin are elevated in both human $(2,3)$ and murine (41) models of obesity, we hypothesized that this hormone may be responsible for the increased levels of PAI-1 observed in obese individuals. To begin to test this hypothesis, we determined the effect of insulin on plasma PAI-1 levels (Fig. 6). Plasma was collected from saline or insulin-treated lean mice and plasma PAI- 1 activity, as well as glucose and insulin levels were determined. Intraperitoneal injection of 10 units of insulin increased total plasma insulin levels from a basal level of $2.3 \pm 0.4 \mathrm{ng} / \mathrm{ml}$ to $25.0 \pm 1.4$ $\mathrm{ng} / \mathrm{ml}$ by $3 \mathrm{hr}$, with a concurrent decrease in plasma glucose levels (Fig. 6B). Plasma PAI-1 (Fig. 6A) increased from the baseline level of $5.3 \pm 0.6 \mathrm{ng} / \mathrm{ml}$ to a maximum of $13.3 \pm 0.3$ 

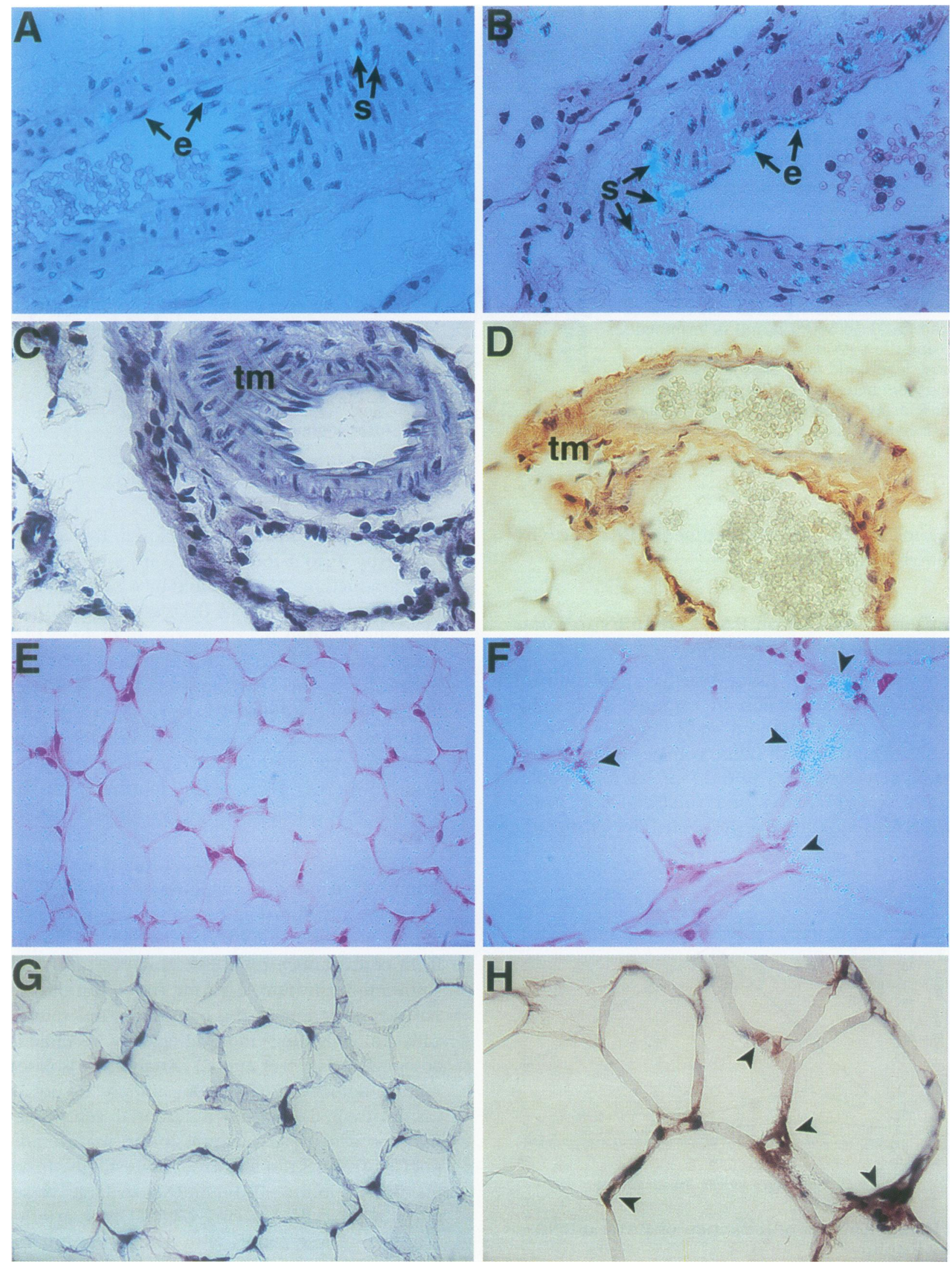

FIG. 5. Cellular localization of PAI-1 mRNA and antigen in the adipose tissue from lean $(+/$ ?) and obese (ob/ob) mice

Vasculature from adipose tissue of lean (A and C) and obese (B and D) mice analyzed for PAI-1 mRNA (A and B)) and antigen $(\mathrm{C}$ and $\mathrm{D})$. Sections of epididymal fat pads containing adipocytes and microvascular endothelial cells from lean ( $E$ and $G$ ) and obese (F and $H$ ) mice analyzed for PAI-1 mRNA (E and F) and antigen (G and $H$ ). e, endothelial cell; s, smooth muscle cells; tm, tunica media, arrowheads, positive cells. Slides for in situ hybridization were exposed for 8 weeks at $4{ }^{\circ} \mathrm{C}$ and stained with hematoxylin and eosin. Slides used for immunohistochemical analysis were counterstained with hematoxylin. Magnification: $400 \times$ for all sections. 
FIG. 6. Effect of insulin on the plasma levels of active PAI-1, glucose, and total insulin in lean mice

Six- to 8-week-old male lean mice were injected intraperitoneally with saline or 10 units regular human insulin. The animals were sacrificed at the indicated times and blood was collected into 20 mM EDTA (final concentration). After centrifugation, the plasma was collected and PAI- 1 activity $(\mathrm{ng} / \mathrm{ml})$ determined using the t-PA binding assay (A). Glucose levels and total plasma insulin levels were determined using the hexokinase assay and a rat insulin RIA assay, respectively $(\mathrm{B})$.

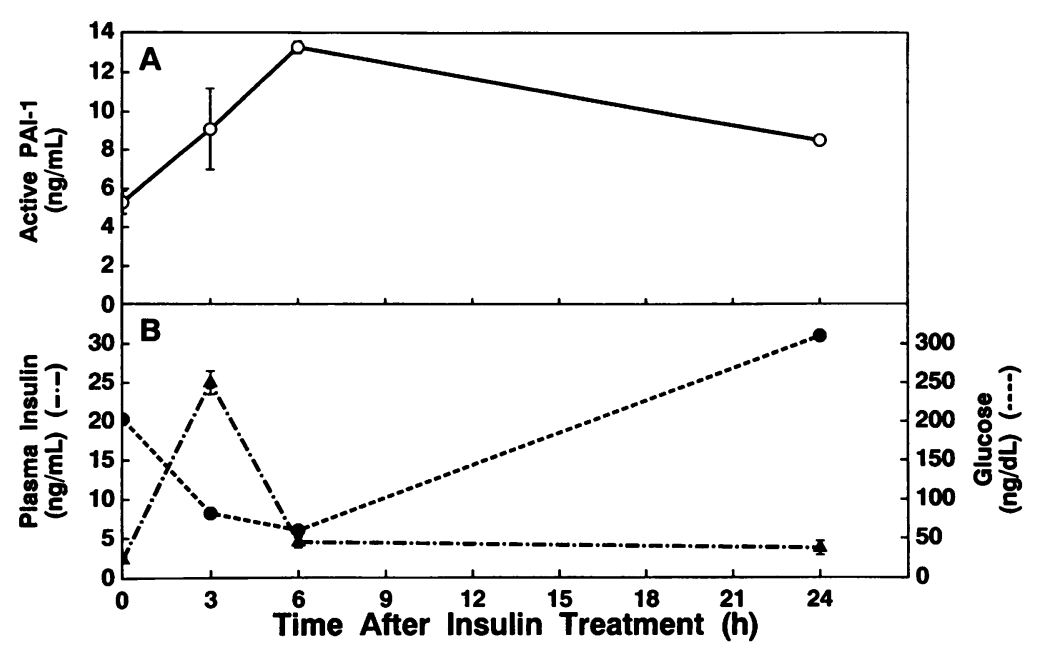

$\mathrm{ng} / \mathrm{ml}$ by $6 \mathrm{hr}$, after which time the PAI-l activity slowly declined.

\section{Effect of Insulin on PAI-1 Gene Expression in Tissues from Lean Mice}

To examine the tissue-specific regulation of PAI-1 gene expression in response to insulin, mice were injected intraperitoneally with 10 units insulin or with saline vehicle alone. Tissues were removed 3, 6, and $24 \mathrm{hr}$ later, and total RNA was prepared and analyzed for PAI-1 mRNA by quantitative RT-PCR (Fig. 7). Insulin

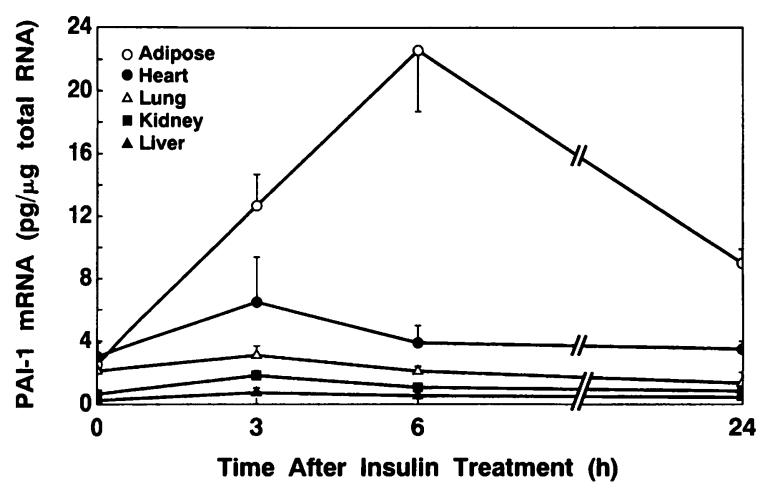

FIG. 7. Kinetics of induction of PAI-1 mRNA by insulin

Six- to 8-week-old lean mice were injected intraperitoneally with 10 units of insulin and the indicated tissues were removed 3, 6, and $24 \mathrm{hr}$ later. Total RNA was prepared and analyzed for PAI-1 gene expression by quantitative RT-PCR as described in Materials and Methods. Each time point on the graph represents the mean $\pm \mathrm{SD}$ of four animals. increased PAI- 1 mRNA expression in the adipose tissues by 3- to 4 -fold within $3 \mathrm{hr}$, with a maximum induction of 6- to 7-fold by $6 \mathrm{hr}$. Although the level of PAI-1 mRNA decreased after $6 \mathrm{hr}$, it was still elevated over controls at $24 \mathrm{hr}$. PAI-1 mRNA was also slightly (2-fold or less) increased by insulin in the heart, lung, kidney, and liver but, unlike the adipose tissue, reached a peak at $3 \mathrm{hr}$ and declined to baseline levels by $24 \mathrm{hr}$. Thus, the regulation of PAI- 1 expression by insulin in vivo is fairly tissue specific, with the adipose tissue being by far the most sensitive tissue.

In situ hybridization experiments were performed to identify the insulin-responsive cells in the adipose tissue (Fig. 8). As already shown in Fig. 5, no PAI-1 mRNA was detected in the fat from control mice (Fig. 8A). However, after insulin administration, a strong hybridization signal was apparent in the adipose tissue, specifically in cells that morphologically resembled adipocytes (Fig. $8 \mathrm{~B}$ and $\mathrm{C}$ ). Analysis of isolated mature adipocytes (37) from adipose tissues of insulin-treated mice by differential centrifugation confirmed PAI- 1 expression in mature adipocytes (results not shown). Interestingly, insulin did not induce PAI-l mRNA in large vessel endothelial cells of veins (Fig. 8C) or arteries (Fig. 8D). These results with insulin are in contrast to the in vivo response observed with agonists such as TNF $\alpha$ and lipopolysaccharide, where both large vessel and microvascular endothelial cells were induced to express PAI-1 mRNA $(27,35)$. Thus, the adipocyte appears to be the major cell type in the adipose tissue respond- 

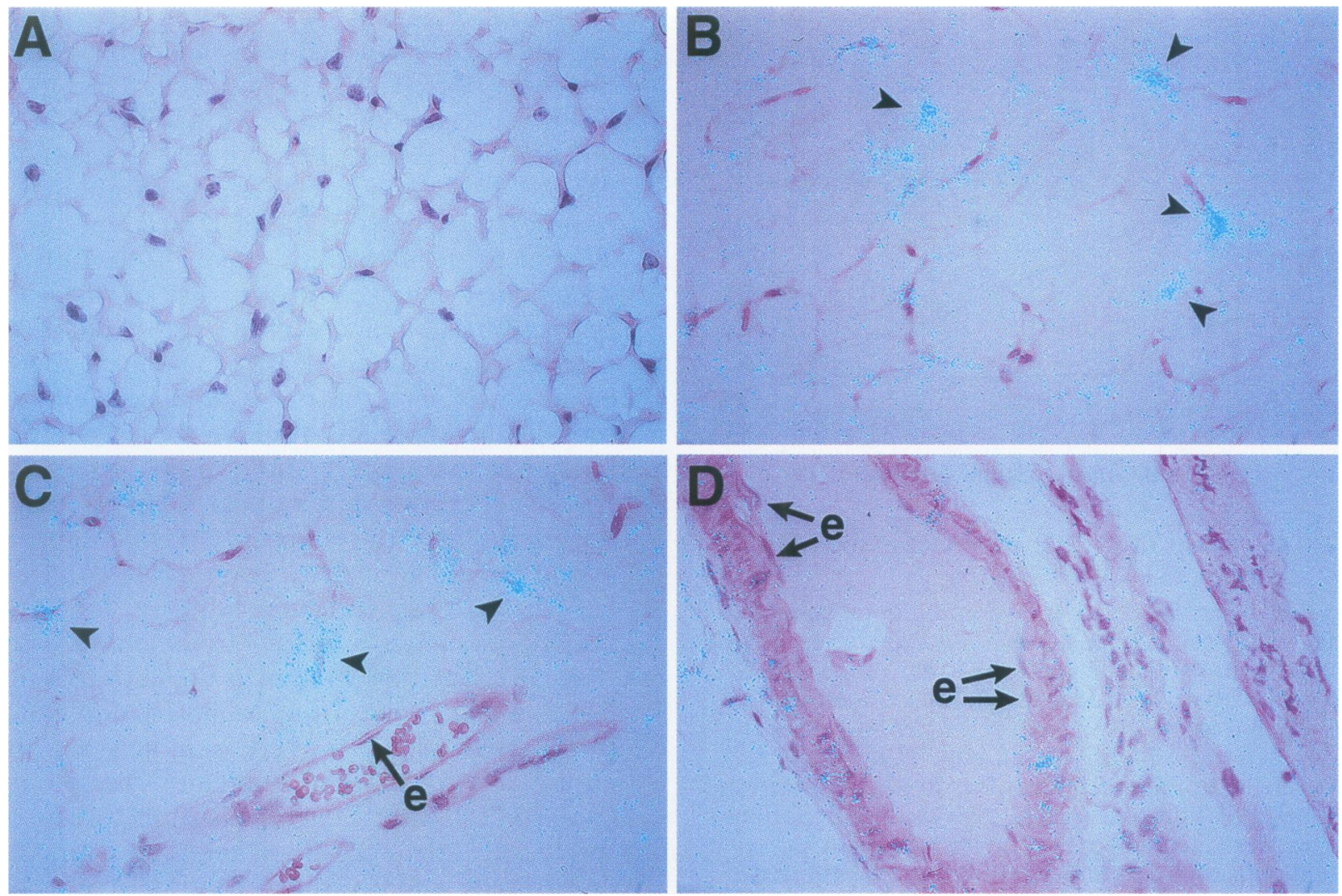

FIG. 8. Effect of insulin on PAI-1 mRNA in the adipose tissue of lean mice

In situ hybridization was performed on paraffin sections of epididymal fat pad from untreated mice (A) and mice treated with insulin (B-D). Slides were exposed for 8 weeks at $4^{\circ} \mathrm{C}$ and stained with hematoxylin and eosin. e, endothelial cell; arrowheads, positive signal for PAI-1 mRNA. Magnification: $400 \times$ for all sections.

ing to insulin with elevated PAI-1 gene expression.

\section{Effect of Insulin on PAI-1 Expression in Cultured 3T3-L1 Adipocytes}

We showed previously that PAI-1 was constitutively synthesized by 3T3-Ll adipocytes and could be induced further by TNF $\alpha$ (27). Experiments were therefore performed to determine whether PAI- 1 expression by 3T3-L1 adipocytes is also induced by insulin. Figure 9 shows that insulin (100 nM; optimized in unpublished dose response experiments) transiently increased PAI-1 mRNA expression in these cells, with a maximum induction of 6- to 7 -fold within $3 \mathrm{hr}$, and a return to baseline levels by $24 \mathrm{hr}$. The rate of accumulation of PAI- 1 antigen in the conditioned medium also was elevated by insulin over a 24-hr period (Fig. 9; inset). These changes in PAI- 1 gene expression in response to insulin are similar to those observed in the adipose tissue in vivo (Fig. 7). Thus, these observations are also consistent with the hypothesis that the adipocyte responds to the increased insulin levels associated with obese/diabetic conditions with increased PAI-1 expression.

\section{DISCUSSION}

Obesity is a pathological condition of the adipose tissue characterized by an increase in the number and the size of the adipocytes themselves (42). Although it is often associated with elevated levels of circulating PAI-1 (4-7), very little is known about the cellular origin and mechanisms that lead to increased PAI-1 under obese conditions. Previous studies from our laboratory on the normal distribution of PAI-1 mRNA in tissues of the mouse demonstrated that the adipose tissue had one of the highest levels of PAI-1 mRNA (13). We also showed that adipocytes themselves constitutively synthesize PAI-1 under normal condi- 


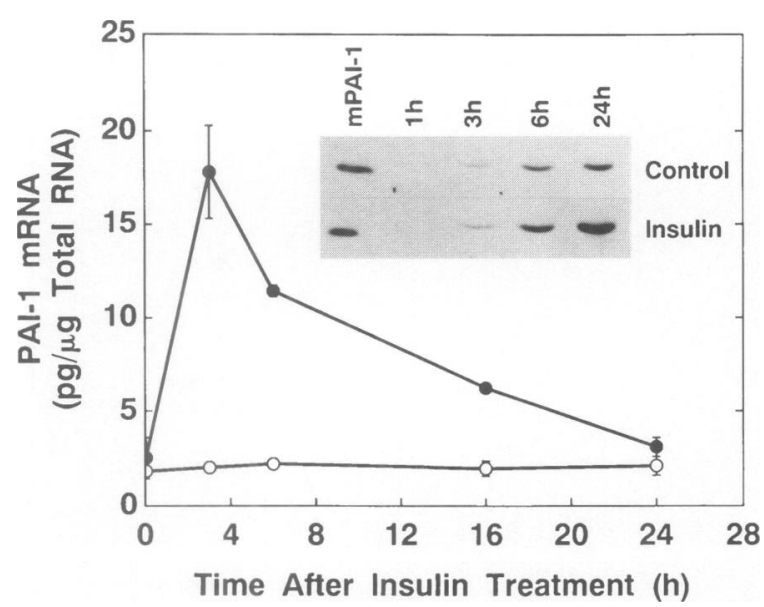

FIG. 9. Effect of insulin on PAI-1 expression by cultured 3T3-L1 adipocytes

3T3-Ll adipocytes were grown and differentiated in 100-mm tissue culture plates as described (36). Total RNA was isolated from untreated cells $(O)$, and cells treated with $100 \mathrm{nM}$ insulin (O) for the indicated times, and the steady-state levels of PAI-1 mRNA were determined using quantitative PCR $(n=6 \pm$ SD). Inset: Conditioned medium $(20 \mu \mathrm{l})$ from untreated cells and cells treated with insulin for various times were electrophoresed under non-reducing conditions on a $9 \%$ SDS-PAGE gel and transferred to nitrocellulose membranes. The membranes were analyzed for PAI-1 by Western blotting using a polyclonal rabbit anti-mouse PAI- 1 antiserum and the enhanced chemiluminescence detection system. mPAI- 1 refers to the recombinant murine PAI-1 antigen used as a standard.

tions, and that they can be induced to synthesize increased levels of PAI-1 in response to agents such as TNF $\alpha$, a cytokine that is elevated in human as well as rodent models of obesity $(23,24)$. These results have led to the hypothesis that PAI-1 expression by cells of the adipose tissue may significantly contribute to the elevated levels of plasma PAI-1 observed under obese conditions, and that agents like TNF $\alpha$ and perhaps insulin, induce PAI- 1 further in these cells. This hypothesis was tested in the current study by using a genetically obese (ob/ob) and lean mouse model.

We demonstrated elevated plasma PAI-1 activity in obese mice which increased further with age, while the activity in the plasma of the lean mice remained relatively constant (Fig. 1). Since elevated plasma PAI- 1 is an independent risk factor for cardiovascular disease, these results suggest that as these obese animals age, their risk for thrombosis will increase. The increase (5- to 6-fold) in PAI-1 mRNA expression observed in the epididymal, subcutaneous, and brown fat of the obese mice (Fig. 2) suggests that the adipose tissue itself may be a significant contributor to the elevated plasma PAI-1 levels observed in obesity. The results are more significant when considered in terms of the increased amount of adipose tissue in obesity, when its cumulated weight may far exceed even that of the liver. Both cell fractionation studies (Fig. 4) and in situ hybridization analysis (Fig. 5, compare E and F) demonstrate that the obese adipocyte express considerably more PAI-1 mRNA than adipocytes isolated from lean mice. PAI- 1 mRNA expression was also increased in the smooth muscle cells of the arteries from the obese mice (Fig. 5, compare A and B). Additionally, occasional large vessel endothelial cells also stained positively for PAI-1 mRNA in adipose tissue from obese mice (Fig. 5B). This observation is significant, since PAI-1 mRNA is not in general detected in endothelial cells under normal conditions in the mouse $(27,35)$. It seems, therefore, that the increase in PAI-1 mRNA in the obese adipose tissue specifically originates from adipocytes, smooth muscle cells, and occasional endothelial cells. In situ hybridization analysis of the heart, lung, kidney, and liver of the obese mice revealed that the small increases in PAI-1 mRNA expression detected in these tissues (Fig. 2) originates from a small percentage $(<1 \%)$ of tissue-specific cells (data not shown). For example, a small percentage of the hepatocytes in the liver from obese mice expressed PAI-1 mRNA as did unidentified cells within the glomerulus of the kidney and cells lining the alveoli in the lung.

Obesity is frequently accompanied by noninsulin-dependent diabetes mellitus and hyperinsulinemia (3). We thus determined the effect of insulin on PAI-1 expression in lean mice (Figs. 6 and 7). Intraperitoneal injection of 10 units of regular insulin to lean mice established a plasma insulin level which is close to the levels observed in the plasma of obese mice (Fig. 6B). Insulin administered in this way increased PAI-1 antigen in plasma (Fig. 6A) and PAI-1 mRNA in the adipose tissue (Fig. 7), in a time-dependent manner, but had little effect on PAI-1 mRNA in other tissues. In situ hybridization analysis revealed that insulin induced PAI-1 mRNA in adipocytes but had no effect on PAI-1 biosynthesis by smooth muscle or endothelial cells (Fig. 8). This lack of response to insulin by endothelial cells in vivo is similar to the lack of response of endothelial cells in vitro (21). Thus, the induc- 
tion of PAI-1 by insulin in the adipose tissue appears to be relatively specific for the adipocyte. It has been suggested that increased hepatic synthesis of PAI-1 may account for its elevation in obese subjects (20). However, only a slight increase (approximately 1.5 - to 2 -fold) in PAI-1 mRNA in the liver was observed after insulin administration in the present study. Thus, the adipose tissue is by far the most responsive tissue in terms of PAI-1 induction. The intraperitoneal injection of insulin into lean mice was followed by a brief period of hypoglycemia (Fig. 6). Therefore, we cannot be certain from the in vivo experiments whether the effect of insulin on PAI-1 expression is direct, or indirect because of the hypoglycemia and associated changes which followed the treatment. In this respect, infusion of insulin into rabbits under conditions of euglycemic control also increased plasma PAI-l activity (43). This observation supports the hypothesis that the observed increases in PAI- 1 in our study result from the direct effects of insulin.

The conclusion that the induction of PAI- 1 is a direct effect of insulin is also supported by the in vitro studies shown in Fig. 9. In vitro, insulin stimulates PAI-1 mRNA expression in HepG2 cells $(20,44)$ and in cultures of human hepatocytes (45) but not in human endothelial cells (21). In the present study, we demonstrate that PAI- 1 mRNA and antigen are induced by insulin in 3T3-Ll adipocytes in a time- and dose-dependent manner (Fig. 9). Although the concentration of insulin used in these in vitro studies is similar to that used in previous in vitro studies $(21,46)$, the level of induction of PAI- 1 in 3T3-Ll adipocytes by insulin was considerably higher than that reported for other cell types (21).

It should be noted that in contrast to the in vitro effects of insulin on PAI-1 expression, the in vivo effects of insulin on PAI-1 synthesis in humans are contradictory. Interventions that increased endogenous insulin levels such as an oral glucose load appeared to be associated with an increase in plasma PAI-l activity in normal and obese subjects (47). Similarly, reduction in endogenous hyperinsulinemia, by fasting or by treatment with metformin decreased plasma PAI-1 $(47,48)$. On the other hand, acute or chronic administration of exogenous insulin to normal or obese subjects either did not change plasma PAI-1 activity or slightly diminished plasma PAI- 1 activity $(19,49-54)$. Long-term insulin treatment suppressed endogenous insulin secretion (19), a finding that may help to explain decreased PAI-1 activity. Additionally, the plasma concentrations of insulin reached after insulin administration to normal human subjects (i.e., $<100 \mu \mathrm{U} / \mathrm{ml}$ ) were less than those usually found in patients with obesity and related NIDDM (49-51). These insulin levels were also less than those achieved in the rabbit study where plasma PAI-1 was increased after insulin infusion (43). Similarly, the injection of insulin into lean mice in the present study established a plasma insulin level that was close to the levels observed in the obese mice.

Interestingly, the adipose tissue is also the major site of elevated TNF $\alpha$ expression in obesity $(23,24)$. In this regard, we recently demonstrated that TNF $\alpha$ induced PAI-1 production in adipocytes, smooth muscle cells, and occasional endothelial cells within the adipose tissues of normal CB6 mice (27). The combined pattern of gene expression in the adipose tissue in response to TNF $\alpha$ (27) and insulin (this study) remarkably resembles what we observed in the adipose tissues of the obese mice (Fig. 5). These results thus support the hypothesis that the elevated levels of PAI-1 observed in obesity result from the combined action of TNF $\alpha$ and insulin.

\section{ACKNOWLEDGMENTS}

The authors thank T. Thinnes and M. Pandey for their technical assistance. In addition we wish to thank M. McRae for her expert secretarial skills. This work was supported by National Institutes of Health Grant HL 47819 to DJL.

\section{REFERENCES}

1. Larsson B. (1991) Obesity, fat distribution and cardiovascular disease. Int. J. Obesity 15: 53-57.

2. Björntorp P. (1992) Abdominal fat distribution and disease: An overview of epidemiological data. Ann. Med. 24: 15-18.

3. DeFronzo RA, Ferrannini E. (1991) Insulin resistance: A multifaceted syndrome responsible for NIDDM, obesity, hypertension, dyslipidemia, and atherosclerotic cardiovascular disease. Diabetes Care 14: 173-194.

4. McGill JB, Schneider DJ, Arfken CL, Lucore CL, Sobel BE. (1994) Factors responsible for impaired fibrinolysis in obese subjects and NIDDM patients. Diabetes 43: 104-109.

5. Potter van Loon BJ, Kluft C, Radder JK, 
Blankenstein MA, Meinders AE. (1993) The cardiovascular risk factor plasminogen activator inhibitor type 1 is related to insulin resistance. Metabolism 42: 945-949.

6. Legnani C, Maccaferri $M$, Tonini $P$, Cassio A, Cacciari E, Coccheri S. (1988) Reduced fibrinolytic response in obese children: Association with high baseline activity of the fast acting plasminogen activator inhibitor (PAI1). Fibrinolysis 2: 211-214.

7. Vague P, Juhan-Vague I, Chabert V, Alessi MC, Atlan C. (1989) Fat distribution and plasminogen activator inhibitor activity in nondiabetic obese women. Metabolism 38: 913-915.

8. Takada Y, Urano T, Watanabe I, Taminato A, Yoshimi T, Takada A. (1993) Changes in fibrinolytic parameters in male patients with type 2 (non-insulin-dependent) diabetes mellitus. Thromb. Res. 71: 405-415.

9. Wada H, Mori Y, Kaneko T, et al. (1993) Elevated plasma levels of vascular endothelial cell markers in patients with hypercholesterolemia. Am. J. Hematol. 44: 112-116.

10. Juhan-Vague I, Moerman B, De Cock F, Aillaud MF, Collen D. (1984) Plasma levels of a specific inhibitor of tissue-type plasminogen activator (and urokinase) in normal and pathological conditions. Thromb. Res. 33: 523-530.

11. Sundell IB, Nilsson TK, Hallmans G, Hellsten G, Dahlen GH. (1989) Interrelationship between plasma levels of plasminogen activator inhibitor, tissue plasminogen activator, lipoprotein(a), and established cardiovascular risk factors in a North Swedish population. Atherosclerosis 80: 9-16.

12. Primrose JN, Davies JA, Prentice CRM, Hughes R, Johnston D. (1992) Reduction in factor VII, fibrinogen and plasminogen activator inhibitor-1 activity after surgical treatment of morbid obesity. Thromb. Haemost. 68: 396-399.

13. Sawdey MS, Loskutoff DJ. (1991) Regulation of murine type 1 plasminogen activator inhibitor gene expression in vivo: Tissue specificity and induction by lipopolysaccharide, tumor necrosis factor- $\alpha$, and transforming growth factor- $\beta$. J. Clin. Invest. 88: 1346-1353.

14. Reaven GM. (1995) Pathophysiology of insulin resistance in human disease. Physiol. Rev. 75: 473-486.

15. Asplund-Carlson A, Hamsten A, Wiman B, Carlson LA. (1993) Relationship between plasma plasminogen activator inhibitor-1 activity and VLDL triglyceride concentration, insulin levels and insulin sensitivity: Studies in randomly selected normo- and hypertriglyceridaemic men. Diabetologia 36: 817-825.

16. Juhan-Vague I, Roul C, Alessi MC, Ardissone JP, Heim M, Vague P. (1989) Increased plasminogen activator inhibitor activity in non-insulin-dependent diabetic patients: Relationship with plasma insulin. Thromb. Haemostas. 61: 370-373.

17. Vague $P$, Juhan-Vague I, Aillaud MF, et al. (1986) Correlation between blood fibrinolytic activity, plasminogen activator inhibitor level, plasma insulin level, and relative body weight in normal and obese subjects. Metabolism 35: 250-253.

18. Mykkänen L, Rönnemaa $T$, Marniemi J, Haffner SM, Bergman R, Laakso M. (1994) Insulin sensitivity is not an independent determinant of plasma plasminogen activator inhibitor-1 activity. Arterioscler. Thromb. 14: 1264-1271.

19. Jain SK, Nagi DK, Slavin BM, Lumb PJ, Yudkin JS. (1993) Insulin therapy in type 2 diabetic subjects suppresses plasminogen activator inhibitor (PAI-1) activity and proinsulinlike molecules independently of glycaemic control. Diabet. Med. 10: 27-32.

20. Alessi MC, Juhan-Vague I, Kooistra T, Declerck PJ, Collen D. (1988) Insulin stimulates the synthesis of plasminogen activator inhibitor 1 by the human hepatocellular cell line Hep G2. Thromb. Haemost. 60: 491-494.

21. Alessi MC, Anfosso F, Henry M, Peiretti F, Nalbone G, Juhan-Vague I. (1995) Up-regulation of PAI-1 synthesis by insulin and proinsulin in HEP G2 cells but not in endothelial cells. Fibrinolysis 9: 237-242.

22. Schneider DJ, Sobel BE. (1991) Augmentation of synthesis of plasminogen activator inhibitor type 1 by insulin and insulin-like growth factor type I: Implications for vascular disease in hyperinsulinemic states. Proc. Natl. Acad. Sci. U.S.A. 88: 9959-9963.

23. Hotamisligil GS, Shargill NS, Spiegelman BM. (1993) Adipose expression of tumor necrosis factor- $\alpha$ : Direct role in obesity-linked insulin resistance. Science 259: 87-91.

24. Hotamisligil GS, Arner P, Caro JF, Atkinson RL, Spiegelman BM. (1995) Increased adipose tissue expression of tumor necrosis factor- $\alpha$ in human obesity and insulin resistance. J. Clin. Invest. 95: 2409-2415.

25. van Hinsbergh VW, Kooistra T, van den Berg 
EA, Princen HM, Fiers W, Emeis JJ. (1988) Tumor necrosis factor increases the production of plasminogen activator inhibitor in human endothelial cells in vitro and in rats in vivo. Blood 72: 1467-1473.

26. Kooistra T. (1990) The use of cultured human endothelial cells and hepatocytes as an in vitro model system to study modulation of endogenous fibrinolysis. Fibrinolysis 4: 33-39.

27. Samad F, Yamamoto K, Loskutoff DJ. (1996) Distribution and regulation of plasminogen activator inhibitor- 1 in murine adipose tissue in vivo: Induction by tumor necrosis factor- $\alpha$ and lipopolysaccharide. J. Clin. Invest. 97: 37-46.

28. Schleef RR, Sinha M, Loskutoff DJ. (1985) Immunoradiometric assay to measure the binding of a specific inhibitor to tissue-type plasminogen activator. J. Lab. Clin. Med. 106: 408-415.

29. Chomczynski P, Sacchi N. (1987) Single-step method of RNA isolation by acid guanidinium thyiocyanate-phenol-chloroform extraction. Anal. Biochem. 162: 156-159.

30. Sawdey M, Podor TJ, Loskutoff DJ. (1989) Regulation of type 1 plasminogen activator inhibitor gene expression in cultured bovine aortic endothelial cells: Induction by transforming growth factor- $\beta$, lipopolysaccharide, and tumor necrosis factor- $\alpha$. J. Biol. Chem. 264: 10396-10401.

31. Feinberg AP, Vogelstein B. (1983) A technique for radiolabeling DNA restriction endonuclease fragments to high specific activity. Anal. Biochem. 132: 6-13.

32. Wang AM, Doyle MV, Mark DF. (1989) Quantitation of mRNA by the polymerase chain reaction. Proc. Natl. Acad. Sci. U.S.A. 86: 9717-9721.

33. Yamamoto K, Loskutoff DJ. (1996) Fibrin deposition in tissues from endotoxin-treated mice correlates with decreases in the expression of urokinase-type but not tissue-type plasminogen activator. J. Clin. Invest. 97: 2440-2451.

34. Vanden Heuvel JP, Tyson FL, Bell DA. (1993) Construction of recombinant RNA templates for use as internal standards in quantitative RT-PCR. BioTechniques 14: 395398.

35. Keeton M, Eguchi Y, Sawdey M, Ahn C, Loskutoff DJ. (1993) Cellular localization of type 1 plasminogen activator inhibitor messenger RNA and protein in murine renal tissue. Am. J. Pathol. 142: 59-70.
36. Reik LM, Maines SM, Ryan DE, Levin W, Bandiera S, Thomas PE. (1987) Isolation of monoclonal antibodies against cytochrome P450 isozymes. J. Immun. Methods 100: 123130.

37. Rodbell M. (1964) Metabolism of isolated fat cells: I. Effects of hormones on glucose metabolism and lipolysis. J. Biol. Chem. 239: 375-380.

38. Green H, Kehinde O. (1975) An established preadipose cell line and its differentiation in culture: II. Factors affecting the adipose conversion. Cell 5: 19-27.

39. Markman B. (1989) Anatomy and physiology of adipose tissue. Clinics in Plastic Surgery 16: 235-243.

40. Jaffe EA, Nachman RL, Becker CG, Minick CR. (1973) Culture of human endothelial cells derived from umbilical cord veins. Identification by morphologic and immunologic criteria. J. Clin. Invest. 52: 2745-2756.

41. Herberg L, Coleman DL. (1977) Laboratory animals exhibiting obesity and diabetes syndromes. Metabolism 26: 59-99.

42. Remacle C, Gregoire F. (1992) Cellular and molecular biology in the study of the physiopathology of obesity. Acta Clin. Belg. 14(Suppl): 3-12.

43. Nordt TK, Sawa H, Fujii S, Sobel BE. (1995) Induction of plasminogen activator inhibitor type-1 (PAI-1) by proinsulin and insulin in vivo. Circulation 91: 764-770.

44. Grant PJ, Ruegg M, Medcalf RL. (1991) Basal expression and insulin-mediated induction of PAI-1 mRNA in Hep G2 cells. Fibrinolysis 5: 81-86.

45. Kooistra T, Bosma PJ, Tons HAM, van den Berg AP, Meyer P, Princen HMG. (1989) Plasminogen activator inhibitor 1: Biosynthesis and mRNA level are increased by insulin in cultured human hepatocytes. Thromb. Haemost. 62: 723-728.

46. Schneider DJ, Nordt TK, Sobel BE. (1993) Attenuated fibrinolysis and accelerated atherogenesis in type II diabetic patients. $D i$ abetes 42: 1-7.

47. Medvescek M, Keber D, Stegnar M, Borovnicar A. (1990) Plasminogen activator inhibitor 1 response to a carbohydrate meal in obese subjects. Fibrinolysis 4(Suppl 2): 89-90.

48. Vague PH, Juhan-Vague I, Alessi MC, Badier C, Valadier J. (1987) Metformin decreases the high plasminogen activator inhibition capacity, plasma insulin and triglyceride lev- 
els in non-diabetic obese subjects. Thromb. Haemost. 58: 326-328.

49. Grant PJ, Kruithof EKO, Felley CP, Felber JP, Backmann F. (1990) Short-term infusions of insulin, triacylglycerol and glucose do not cause acute increases in plasminogen activator inhibitor-1 concentrations in man. Clin. Sci. 79: 513-516.

50. Landin $\mathrm{K}$, Tengborn L, Chmielewska J, von Schenck H, Smith U. (1991) The acute effect of insulin on tissue plasminogen activator and plasminogen activator inhibitor in man. Thromb. Haemostas. 65: 130-133.

51. Vuorinen-Markkola H, Puhakainen I, YkiJarvinen H. (1992) No evidence for shortterm regulation of plasminogen activator in- hibitor activity by insulin in man. Thromb. Haemost. 67: 117-120.

52. Potter van Loon BJ, De Bart ACW, Radder JK, Frölich M, Kluft C, Meinders AE. (1990) Acute exogenous hyperinsulinemia does not result in elevation of plasma plasminogen activator inhibitor-1 (PAI-1) in humans. Fibrinolysis 4(Suppl 2): 93-94.

53. Juhan-Vague I, Vague P. (1991) Hypofibrinolysis and insulin-resistance. Diabete Metab. 17: $96-100$.

54. Teufelsbauer H, Proidl S, Havel M, Vukovich T. (1992) Early activation of hemostasis during cardiopulmonary bypass: Evidence for thrombin mediated hyperfibrinolysis. Thromb. Haemost. 68: 250-252.

Contributed by A. Cerami on June 27, 1996. 